\title{
Aeromonas molluscorum sp. nov., isolated from bivalve molluscs
}

\author{
David Miñana-Galbis, Maribel Farfán, M. Carme Fusté \\ and J. Gaspar Lorén
}

Correspondence

J. Gaspar Lorén jgloren@ub.edu
The genus Aeromonas Stanier 1943 comprises a collection of Gram-negative, rod-shaped, non-spore-forming, oxidaseand catalase-positive, glucose-fermenting, facultatively anaerobic bacteria that are resistant to vibriostatic agent $\mathrm{O} / 129$ and are generally motile by means of polar flagella (Popoff, 1984; Euzéby, 1998). The genus Aeromonas belongs to the family Aeromonadaceae within the $\gamma$-Proteobacteria. Aeromonads are autochthonous to aquatic environments worldwide and are usual microbiota (as well as primary or secondary pathogens) of fish, amphibians and other animals. Some motile species (mainly Aeromonas caviae, Aeromonas hydrophila and Aeromonas veronii bv. Sobria) are opportunistic pathogens of humans (Janda \& Abbott, 1998).

The taxonomy of the genus Aeromonas appears to change

Published online ahead of print on 15 June 2004 as DOI 10.1099/ ijs.0.63202-0.

Abbreviations: $A D H$, arginine dehydrolase; AFLP, amplified fragment length polymorphism; HG, hybridization group; LDC, lysine decarboxylase; MR, methyl red; ODC, ornithine decarboxylase; VP, VogesProskauer

The GenBank/EMBL/DDBJ accession numbers for the $16 \mathrm{~S}$ rRNA gene sequences of strains $93 \mathrm{M}, 431 \mathrm{E}, 848 \mathrm{~T}^{\top}, 849 \mathrm{~T}$ and $869 \mathrm{~N}$ are AY532688-AY532692, respectively.

A dendrogram of AFLP profiles and tables showing 165 rRNA gene sequence similarities and DNA-DNA hybridization data are available as supplementary material in IJSEM Online. continually, due to the addition of newly described species and the reclassification or extended description of existing taxa. Since the first DNA-DNA hybridization study that was performed on Aeromonas (Popoff et al., 1981) and the description of the genus with four phenospecies (A. caviae, A. hydrophila, Aeromonas salmonicida and A. sobria) in Bergey's Manual of Systematic Bacteriology (Popoff, 1984), 18 Aeromonas species have been described: A. hydrophila, Aeromonas bestiarum, A. salmonicida, A. caviae, Aeromonas media, Aeromonas eucrenophila, Aeromonas sobria, Aeromonas jandaei, A. veronii, Aeromonas sp. HG11, Aeromonas schubertii, Aeromonas sp. HG13 (enteric Group 501), Aeromonas trota, Aeromonas allosaccharophila, Aeromonas encheleia, Aeromonas popoffii, Aeromonas culicicola and the most recently described species, Aeromonas simiae (Huys et al., 2002; Pidiyar et al., 2002; Esteve et al., 2003; HarfMonteil et al., 2004).

The present investigation was initiated to determine the taxonomic position of a group of five strains that were isolated from bivalve molluscs, which clustered together as a separate phenon (phenon VI) in a previous phenotypic study (Miñana-Galbis et al., 2002). We have completed the phenotypic study and subjected this group of strains to amplified fragment length polymorphism (AFLP) analysis, 16S rRNA gene sequencing, DNA G + C content determination and DNA-DNA homology determination. In this genotypic study, we included the reference strains 
of the Aeromonas DNA hybridization groups (HGs) that are currently described. The data indicated that our strains are genotypically and phenotypically distinct from the Aeromonas species that have been accepted until now and that they constitute a homogeneous taxon, for which the name Aeromonas molluscorum sp. nov. is proposed.

The five strains $848 \mathrm{~T}^{\mathrm{T}}\left(=\right.$ CECT $\left.5864^{\mathrm{T}}=\mathrm{LMG} 22214^{\mathrm{T}}\right)$, 93M (=CECT $5865=\mathrm{LMG}$ 22215), 431E (=CECT $5866=\mathrm{LMG} 22216), 849 \mathrm{~T}(=\mathrm{CECT} 5867=\mathrm{LMG} 22217)$ and $869 \mathrm{~N}(=$ CECT $5868=$ LMG 22218) were isolated from wedge-shells (Donax trunculus), mussels (Mytilus sp.), cockles (Cardium sp.), wedge-shells (Donax trunculus) and razor-shells (Ensis sp.), respectively, from various retail markets in Barcelona (Spain) between April and October 1997. Bivalves without their shells $(25 \mathrm{~g})$ were suspended 1/10 (w/v) in 1/4 Ringer's solution for homogenization in a Masticator (IUL Instruments). Samples and serial dilutions were cultured on $\mathrm{m}$-Aeromonas selective agar base Havelaar (Biolife) and the same medium with $10 \mathrm{mg}$ ampicillin $\mathrm{l}^{-1}$ for $24-48 \mathrm{~h}$ at $25^{\circ} \mathrm{C}$. Samples were also enriched in tryptone soy broth (TSB) and alkaline peptone water $(\mathrm{pH} \mathrm{9.0)}$ overnight and then inoculated on the above-mentioned media. Isolates were grown on tryptone soy agar (TSA) for purification and further study. Strains were maintained in TSB with $20 \%$ (v/v) glycerol at $-40{ }^{\circ} \mathrm{C}$.

Cell size, morphology and flagellar arrangement were determined by transmission electron microscopy (JEOL 1010). Cells were grown on TSA supplemented with $0.5 \%$ (w/v) $\mathrm{NaCl}$ for $48 \mathrm{~h}$ at $25^{\circ} \mathrm{C}$ and, after further suspension in MilliQ water, were examined by negative staining with $2 \%(\mathrm{w} / \mathrm{v})$ uranyl acetate.

Physiological and biochemical characterization, unless otherwise stated, was performed at $25^{\circ} \mathrm{C}$ and all media contained 1\%(w/v) $\mathrm{NaCl}$ (Miñana-Galbis et al., 2002). Gram-staining, motility, glucose oxidation-fermentation test, oxidase and catalase activity, nitrate reduction, indole production, susceptibility to vibriostatic agent $\mathrm{O} / 129$, swarming motility, production of a brown diffusible pigment, gas production from D-glucose, methyl red (MR) and Voges-Proskauer (VP) reactions, $\beta$-galactosidase activity (ONPG), hydrogen sulfide production from cysteine and thiosulfate, growth on MacConkey agar, salt tolerance, $\mathrm{pH}$ and temperature ranges for growth, acid production from carbohydrates, hydrolysis of arbutin, DNA, elastin, aesculin, starch, urea and xanthine, utilization of substrates as sole carbon and energy sources and sensitivity to antibiotics were determined as described previously (Miñana-Galbis et al., 2002). Arginine dehydrolase $(\mathrm{ADH})$, lysine decarboxylase (LDC) and ornithine decarboxylase (ODC) activity (Moeller's method) and gelatin hydrolysis by using tannic acid $(1 \%)$ as the gelatin-precipitating reagent were determined as described by Smibert \& Krieg (1994).

For 16S rRNA gene sequencing and phylogenetic analysis,
DNA was extracted by using a REALPURE genomic DNA extraction kit (RBMEG03; Durviz). Oligonucleotide primers used for PCR amplification and sequencing of the $16 \mathrm{~S}$ rRNA gene were those described by Martínez-Murcia et al. (1999). DNA was subjected to PCR amplification in a total volume of $50 \mu \mathrm{l}$ that contained $50 \mathrm{mM} \mathrm{KCl,} 15 \mathrm{mM}$ Tris/HCl ( $\mathrm{pH} 8.0$ ), $1.5 \mathrm{mM} \mathrm{MgCl}, 0.2 \mathrm{mM}$ each deoxyribonucleotide (dATP, dCTP, dGTP, dTTP; Amersham Biosciences), 1.25 U AmpliTaq Gold DNA polymerase (Applera) and 25 pmol each primer. The reaction mixtures were subjected to the following thermal cycling: an initial single step of $95^{\circ} \mathrm{C}$ for $9 \mathrm{~min}, 30$ cycles of $94^{\circ} \mathrm{C}$ for $60 \mathrm{~s}$, $51^{\circ} \mathrm{C}$ for $30 \mathrm{~s}$ and $72^{\circ} \mathrm{C}$ for $90 \mathrm{~s}$, and a final single step of $72{ }^{\circ} \mathrm{C}$ for $10 \mathrm{~min}$. PCR products were purified by using Montage PCR centrifugal filter devices (Millipore) and prepared for sequencing by employing a BigDye Terminator v3.1 cycle sequencing kit (Applera). The amplified $16 \mathrm{~S}$ rRNA genes were sequenced with an ABI PRISM 3730 DNA analyser by the Scientific and Technical Services of Barcelona University.

The sequences obtained were aligned with 16S rRNA gene sequences of the type strains of all members of the genus Aeromonas that were available in GenBank by using the CLUSTAL_X program version 1.8 (Thompson et al., 1997). Distances and clustering with the neighbour-joining and maximum-parsimony methods (pairwise deletion and Kimura two-parameter model) were determined by using the MEGA program version 2.1 (Kumar et al., 2001). Stability of the relationships was assessed by bootstrapping (1000 replicates).

AFLP analysis, which included DNA extraction and purification (Pitcher et al., 1989), AFLP fingerprinting, data processing and numerical analysis (Huys \& Swings, 1999), was performed by the BCCM/LMG (Belgian Coordinated Collections of Microorganisms/Laboratorium voor Microbiologie from Universiteit Gent) Identification Service.

For DNA-DNA hybridization and determination of DNA $\mathrm{G}+\mathrm{C}$ content, genomic DNA of bacterial strains was prepared according to a modification of the procedure of Wilson (1987). The $\mathrm{G}+\mathrm{C}$ content of each DNA sample was determined by three independent analyses using the HPLC technique (Mesbah et al., 1989). DNA-DNA hybridizations were performed in four replicates at $47^{\circ} \mathrm{C}$ according to a modification of the method described by Ezaki et al. (1989). These analyses were performed by the BCCM/LMG Identification Service.

The five strains isolated from bivalve molluscs $\left(848 \mathrm{~T}^{\mathrm{T}}\right.$, $93 \mathrm{M}, 431 \mathrm{E}, 849 \mathrm{~T}$ and $869 \mathrm{~N}$ ) were identified as belonging to the genus Aeromonas as they were Gram-negative, rodshaped, motile by one polar flagellum, oxidase-positive, facultatively anaerobic, glucose-fermentative and resistant to vibriostatic agent $\mathrm{O} / 129$ and could grow in the absence of $\mathrm{NaCl}$, but not at $6 \%(\mathrm{w} / \mathrm{v}) \mathrm{NaCl}$. Cells of all isolates were about $1 \cdot 2-2 \cdot 2 \times 0 \cdot 5-1 \cdot 0 \mu \mathrm{m}$ in size. Their antibioticresistance pattern was similar to that of all Aeromonas 
species (Kämpfer et al., 1999). These strains formed nonpigmented, circular colonies with a diameter of 3-4 $\mathrm{mm}$ on TSA when incubated at $25^{\circ} \mathrm{C}$. The growth-temperature range was $4-37^{\circ} \mathrm{C}$ and optimal growth occurred at $25-30^{\circ} \mathrm{C}$.

The novel mesophilic species showed several differentiating phenotypic features in relation to other mesophilic Aeromonas species (Table 1). Four or more tests allowed differentiation of A. molluscorum from all Aeromonas species except A. caviae, A. media and A. simiae. Negative reactions in the tests for indole production and starch hydrolysis allowed the separation of A. molluscorum from A. caviae. Brown pigment production and the abovementioned tests discriminated A. molluscorum from $A$. media. A. molluscorum could be differentiated from A. simiae by lysine decarboxylation and acid production from L-arabinose and D-mannitol. These results allowed the phenotypic discrimination of A. molluscorum from all Aeromonas taxa that have been described to date.

Phylogenetic analysis of $16 \mathrm{~S}$ rRNA gene sequences of isolates of A. molluscorum showed an intraspecies range of zero to three nucleotide differences (Table 2). These sequences were compared with 16S rRNA gene sequences of all type/ reference strains of Aeromonas species and subspecies, including the recently described A. simiae (Harf-Monteil et al., 2004). The phylogenetic tree constructed by the neighbour-joining method is shown in Fig. 1. A. encheleia was the closest neighbour of A. molluscorum, with an interspecies range of one to four nucleotide differences (Table 2). Species and subspecies of the genus Aeromonas exhibited high levels of overall 16S rRNA gene sequence similarity to each other; the number of nucleotide differences ranged from 0 to 48 (see Supplementary Table A in IJSEM Online). $16 \mathrm{~S}$ rRNA gene sequence similarity between A. molluscorum and A. simiae was below $97 \%$, indicating that they represent different species (Stackebrandt \& Goebel, 1994). On the other hand, it is noteworthy that the $16 \mathrm{~S}$ rRNA gene sequence of $A$. hydrophila subsp. dhakensis exhibited a significant number of differences (12-13 nt) from the sequences of the other $A$. hydrophila subspecies and was related closely to A. caviae and A. trota. This result was unexpected, as A. hydrophila subsp. dhakensis shows high relatedness to A. hydrophila subsp. hydrophila and A. hydrophila subsp. ranae by AFLP fingerprinting and DNA-DNA hybridization (Huys et al., 2003) and, at

Table 1. Key tests for the phenotypic differentiation of $A$. molluscorum from other mesophilic Aeromonas species

Data were taken from Carson et al. (2001), Miñana-Galbis et al. (2002) and Valera \& Esteve (2002) unless otherwise indicated. Taxa are identified as: 1, A. molluscorum (data from this study); 2, A. hydrophila (Carson et al., 2001; Huys et al., 2002; Miñana-Galbis et al., 2002; Valera \& Esteve, 2002); 3, A. bestiarum; 4, A. salmonicida (Miñana-Galbis et al., 2002); 5, A. caviae; 6, A. media; 7, A. eucrenophila; 8, A. sobria; 9, A. veronii bv. Sobria; 10, A. jandaei (Carson et al., 2001; Miñana-Galbis et al., 2002; Valera \& Esteve, 2002; Esteve et al., 2003); 11, A. veronii bv. Veronii; 12, A. schubertii; 13, A. trota; 14, A. allosaccharophila; 15, A. encheleia; 16, A. popoffii (Huys et al., 1997; Esteve et al., 2003); 17, A. culicicola (Pidiyar et al., 2002); 18, A. simiae (Harf-Monteil et al., 2004). Abbreviations: +, 85-100\% of strains positive; ,$- 0-15 \%$ of strains positive; $\mathrm{v}+, 50-84 \%$ of strains positive; $\mathrm{v}-, 16-49 \%$ of strains positive; d, different results depending on abovementioned references; ND, no data available.

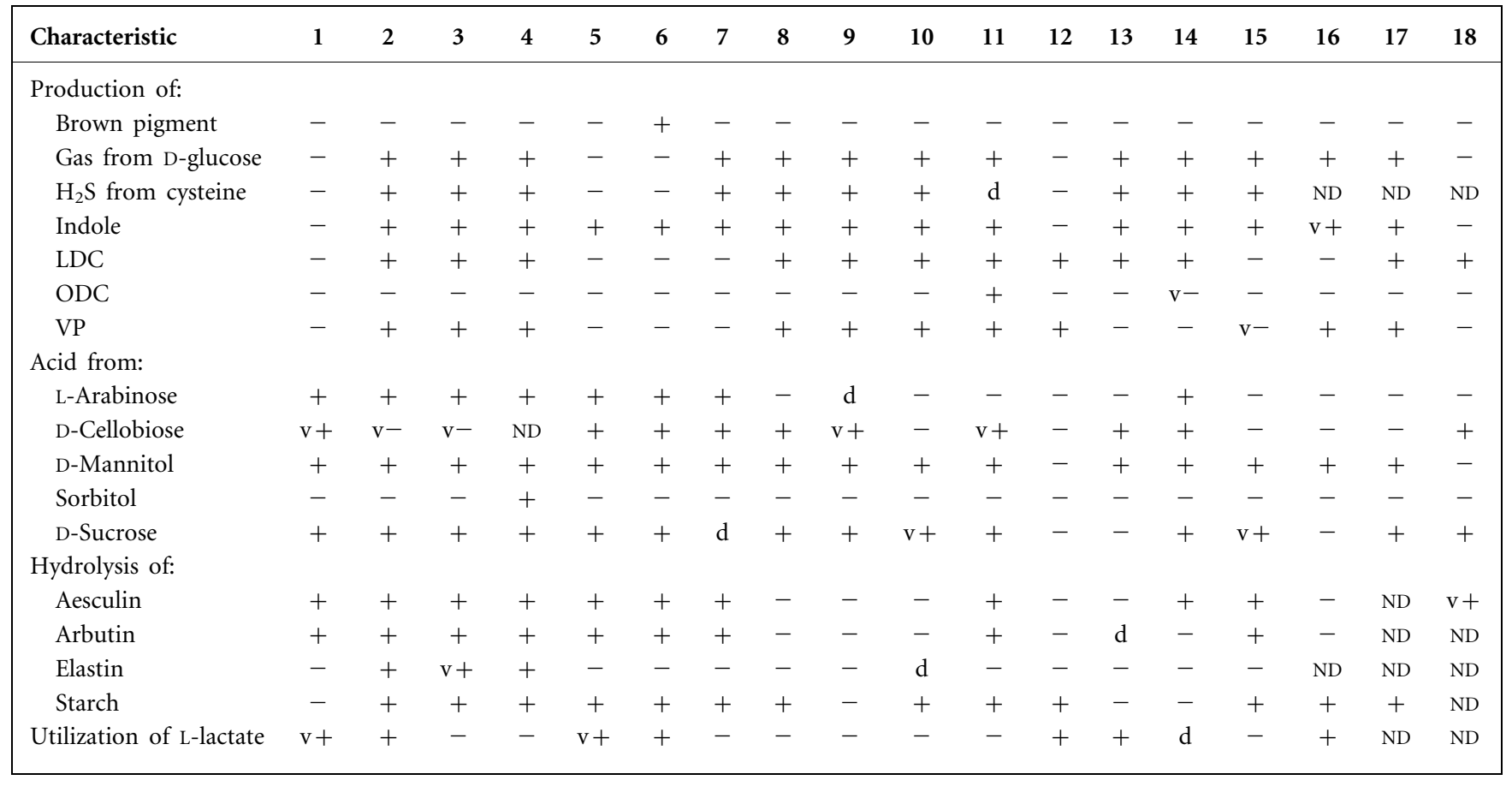


Table 2. Base differences in 16S rRNA gene sequence between the type strain of $A$. encheleia and $A$. molluscorum strains

\begin{tabular}{|c|c|c|c|c|c|c|c|}
\hline \multirow[t]{2}{*}{ Strain } & \multirow{2}{*}{$\begin{array}{c}\text { GenBank } \\
\text { accession number }\end{array}$} & \multicolumn{6}{|c|}{ Position* } \\
\hline & & 258 & 471 & 1011 & 1018 & 1355 & 1367 \\
\hline A. molluscorum 93M & AY532688 & A & Y & $\mathrm{C}$ & G & G & $\mathrm{C}$ \\
\hline A. molluscorum 431E & AY532689 & A & $\mathrm{C}$ & $\mathrm{Y}$ & $\mathrm{R}$ & G & $\mathrm{C}$ \\
\hline A. molluscorum $848 \mathrm{~T}^{\mathrm{T}}$ & AY532690 & A & $\mathrm{T}$ & $\mathrm{T}$ & A & G & $\mathrm{C}$ \\
\hline A. molluscorum $869 \mathrm{~N}$ & AY532692 & A & $\mathrm{C}$ & $\mathrm{C}$ & $\mathrm{R}$ & G & $\mathrm{C}$ \\
\hline
\end{tabular}

${ }^{\star}$ Referring to the Escherichia coli sequence numbering system described by Brosius et al. (1978).

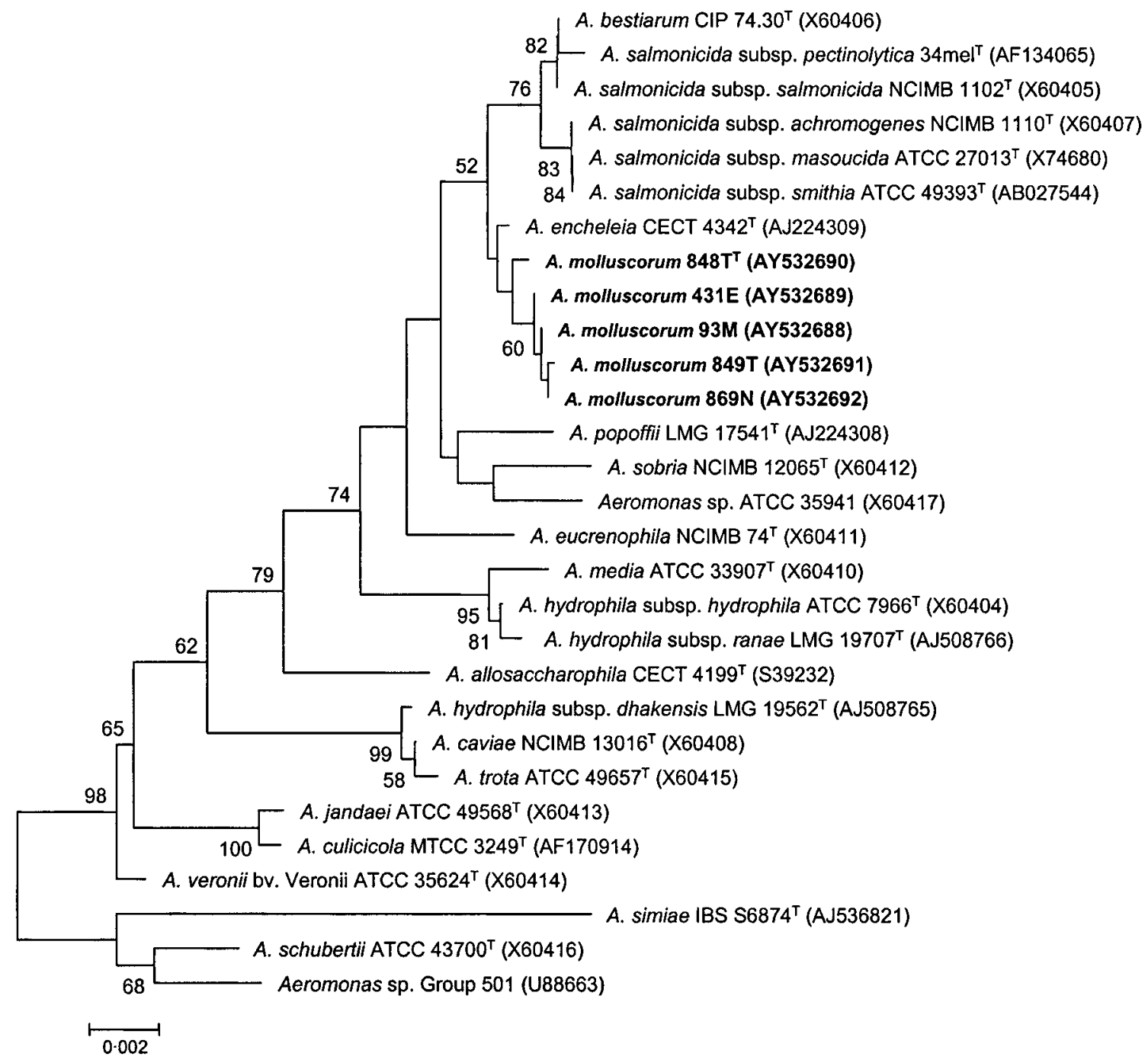

Fig. 1. Phylogenetic relationships of $A$. molluscorum to type/reference strains of the genus Aeromonas. The phylogenetic tree was constructed by using 1544 nt of $16 \mathrm{~S}$ rRNA gene sequence by the neighbour-joining method in the MEGA program version 2.1. Bootstrap values (>50\%) after 1000 replicates are shown. Bar, distance value of 0.002 (calculated in MEGA). 
present, Aeromonas strains that belong to the same species have never shown a phylogenetic divergence of 12-13 nucleotide positions, constituting different phylogenetic lines (Martínez-Murcia, 1999).

The AFLP banding patterns of our five strains were compared with the laboratory database AEROLIB, which comprises well-characterized strains of all Aeromonas DNA HGs that are currently described (Huys \& Swings, 1999; Huys et al., 2003). This comparison revealed that the five isolates form a homogeneous cluster, delineated at a correlation level of $72 \%$. The simplified dendrogram (see Supplementary Figure in IJSEM Online) shows clearly that A. molluscorum constitutes a new AFLP group with low genotypic relatedness to other members of the genus Aeromonas. These results allow the genotypic discrimination of A. molluscorum from other Aeromonas species.

The DNA G+C content of strains $93 \mathrm{M}, 431 \mathrm{E}, 848 \mathrm{~T}^{\mathrm{T}}$, $849 \mathrm{~T}$ and $869 \mathrm{~N}$ was $59 \cdot 0-59 \cdot 4 \mathrm{~mol} \%$, which agrees with the range described for the genus Aeromonas (57-63 mol\%; Holt et al., 1994). Results of DNA-DNA hybridization experiments are summarized in Supplementary Table B in IJSEM Online. We chose two representative isolates from the novel Aeromonas species, the type strain $\left(848 \mathrm{~T}^{\mathrm{T}}\right)$ and strain 93M. These two strains showed $93 \%$ DNA-DNA similarity, clearly above the level of $70 \%$ that is accepted as the limit for species delineation (Wayne et al., 1987). The type strain of A. molluscorum clearly showed $<70 \%$ DNA-DNA similarity (27-45\%) with any of the type/ reference strains of the current Aeromonas HGs. Therefore, A. molluscorum constitutes a new Aeromonas HG.

Based on the results of DNA-DNA hybridization, phenotypic characterization, AFLP analysis and 16S rRNA gene sequencing, we propose that strains $93 \mathrm{M}, 431 \mathrm{E}, 848 \mathrm{~T}^{\mathrm{T}}$, $849 \mathrm{~T}$ and $869 \mathrm{~N}$ represent a novel species within the genus Aeromonas, for which we propose the name Aeromonas molluscorum sp. nov.

\section{Description of Aeromonas molluscorum sp. nov.}

Aeromonas molluscorum (mol.lus.co'rum. N.L. pl. n. Mollusca a zoological phylum; N.L. gen. pl. n. molluscorum of molluscs classified in the phylum Mollusca).

Cells are Gram-negative, straight, motile rods with a polar flagellum, $1 \cdot 2-2 \cdot 2 \mu \mathrm{m}$ long and $0 \cdot 5-1 \cdot 0 \mu \mathrm{m}$ wide. Colonies on TSA are $3-4 \mathrm{~mm}$ in diameter, translucent to opaque, circular and beige in colour after $48 \mathrm{~h}$ at $25^{\circ} \mathrm{C}$. Growth occurs at $4-37^{\circ} \mathrm{C}$, but not at $40 \cdot 5^{\circ} \mathrm{C}$; optimal growth occurs at $25-30{ }^{\circ} \mathrm{C}$. Oxidase- and catalase-positive, reduces nitrate to nitrite and is resistant to vibriostatic agent $\mathrm{O} / 129$ $(150 \mu \mathrm{g})$. Indole, brown diffusible pigment, swarming, gas from D-glucose and hydrogen sulfide from cysteine and thiosulfate are not produced. Positive for glucose oxidationfermentation, ADH, MR and ONPG tests. Negative for VP, LDC and ODC tests. Grows on MacConkey agar. Able to grow at $0-3 \% \mathrm{NaCl}$ and $\mathrm{pH} 9 \cdot 0$, but not at $6 \% \mathrm{NaCl}$ or
$\mathrm{pH} 4 \cdot 5$. All strains hydrolyse arbutin, DNA, aesculin and gelatin, but not starch, elastin, urea or xanthine. All strains produce acid from L-arabinose, arbutin (except strain 93M), D-cellobiose (except strain 431E), dextrin, Dgalactose, glycerol, D-mannitol, D-mannose, D-sucrose and D-trehalose, but not from lactose, D-melibiose, D-raffinose, L-rhamnose, sorbitol or D-xylose. The following substrates are used as sole carbon and energy sources: acetate (except strain 93M), L-arabinose, arbutin, L-arginine, Dcellobiose (except strain 431E), citrate, aesculin, D-fructose, D-galactose, D-glucose, glycerol, L-histidine, maltose, D-mannitol, D-mannose, $\mathrm{N}$-acetylglucosamine, D-sucrose, salicin (except strain 93M) and D-trehalose. None of the strains uses adonitol, dulcitol, inositol, inulin, lactose, Dmelezitose, D-melibiose, D-raffinose, L-rhamnose, sorbitol, L-sorbose or D-xylose. All strains are resistant to ampicillin $(10 \mu \mathrm{g})$ (except strain $431 \mathrm{E})$, erythromycin $(15 \mu \mathrm{g})$ and penicillin $\mathrm{G}(10 \mu \mathrm{g})$. All strains show intermediate sensitivity to streptomycin $(10 \mu \mathrm{g})$ and are sensitive to amikacin $(30 \mu \mathrm{g})$, amoxycillin + clavulanic acid $(30 \mu \mathrm{g})$ (intermediate sensitivity for strains $93 \mathrm{M}$ and $869 \mathrm{~N})$, cefoxitin $(30 \mu \mathrm{g})$ (except strain $93 \mathrm{M})$, ceftriaxon $(30 \mu \mathrm{g})$, cefuroxime $(30 \mu \mathrm{g})$, cephalothin $(30 \mu \mathrm{g})$ (except strains $93 \mathrm{M}$ and $869 \mathrm{~N})$, ciprofloxacin $(5 \mu \mathrm{g})$, colistin $(50 \mu \mathrm{g})$, gentamicin $(10 \mu \mathrm{g})$, imipenem $(10 \mu \mathrm{g})$, polymyxin $\mathrm{B}(300 \mathrm{U})$, tetracycline $(30 \mu \mathrm{g})$, tobramycin $(10 \mu \mathrm{g})$ and trimethoprim + sulfamethoxazole $(1 \cdot 25 \mu \mathrm{g}+23 \cdot 75 \mu \mathrm{g})$. DNA G $+\mathrm{C}$ content is $59 \cdot 0-59 \cdot 4 \mathrm{~mol} \%$.

The type strain, $848 \mathrm{~T}^{\mathrm{T}}\left(=\right.$ CECT $\left.5864^{\mathrm{T}}=\mathrm{LMG} 22214^{\mathrm{T}}\right)$, was isolated from wedge-shells (Donax trunculus) obtained from a retail market in Barcelona (Spain) in 1997.

\section{Acknowledgements}

We thank M. Vinyas and J. Vidal for 16S rRNA gene sequencing assistance. We acknowledge the Serveis Cientificotècnics de la Universitat de Barcelona (Unitat de Microscopia Electrònica \& Servei de Seqüenciació) for assistance. We acknowledge the BCCM/LMG Identification Service of Gent University for performing the DNA $\mathrm{G}+\mathrm{C}$ content determination and AFLP and DNA-DNA hybridization analyses. We thank Dr H. G. Trüper for helping with the nomenclature of the novel species. We thank Dr A. Juárez for his support. This work was supported by a grant from Vicerectorat de Recerca de la Universitat de Barcelona.

\section{References}

Brosius, J., Palmer, M. L., Kennedy, P. J. \& Noller, H. F. (1978). Complete nucleotide sequence of a $16 \mathrm{~S}$ ribosomal RNA gene from Escherichia coli. Proc Natl Acad Sci U S A 75, 4801-4805.

Carson, J., Wagner, T., Wilson, T. \& Donachie, L. (2001). Miniaturized tests for computer-assisted identification of motile Aeromonas species with an improved probability matrix. $J$ Appl Microbiol 90, 190-200.

Esteve, C., Valera, L., Gutiérrez, C. \& Ventosa, A. (2003). Taxonomic study of sucrose-positive Aeromonas jandaei-like isolates from faeces, water and eels: emendation of A. jandaei Carnahan et al. 1992. Int J Syst Evol Microbiol 53, 1411-1419. 
Euzéby, J. P. (1998). Necessary corrections according to Judicial Opinions 16, 48 and 52. Int J Syst Bacteriol 48, 613.

Ezaki, T., Hashimoto, Y. \& Yabuuchi, E. (1989). Fluorometric deoxyribonucleic acid-deoxyribonucleic acid hybridization in microdilution wells as an alternative to membrane filter hybridization in which radioisotopes are used to determine genetic relatedness among bacterial strains. Int J Syst Bacteriol 39, 224-229.

Harf-Monteil, C., Le Flèche, A., Riegel, P., Prévost, G., Bermond, D., Grimont, P. A. D. \& Monteil, H. (2004). Aeromonas simiae sp. nov., isolated from monkey faeces. Int J Syst Evol Microbiol 54, 481-485.

Holt, J. C., Krieg, N. R., Sneath, P. H. A., Stanley, J. Y. \& Williams, S. T. (1994). Subgroup 2: family Vibrionaceae. In Bergey's Manual of Determinative Bacteriology, 9th edn, pp. 190-274. Baltimore: Lippincott Williams \& Wilkins.

Huys, G. \& Swings, J. (1999). Evaluation of a fluorescent amplified fragment length polymorphism (FAFLP) methodology for the genotypic discrimination of Aeromonas taxa. FEMS Microbiol Lett 177, 83-92.

Huys, G., Kämpfer, P., Altwegg, M. \& 7 other authors (1997). Aeromonas popoffii sp. nov., a mesophilic bacterium isolated from drinking water production plants and reservoirs. Int J Syst Bacteriol 47, 1165-1171.

Huys, G., Kämpfer, P., Albert, M. J., Kühn, I., Denys, R. \& Swings, J. (2002). Aeromonas hydrophila subsp. dhakensis subsp. nov., isolated from children with diarrhoea in Bangladesh, and extended description of Aeromonas hydrophila subsp. hydrophila (Chester 1901) Stanier 1943 (Approved Lists 1980). Int J Syst Evol Microbiol 52, 705-712.

Huys, G., Pearson, M., Kämpfer, P., Denys, R., Cnockaert, M., Inglis, V. \& Swings, J. (2003). Aeromonas hydrophila subsp. ranae subsp. nov., isolated from septicaemic farmed frogs in Thailand. Int J Syst Evol Microbiol 53, 885-891.

Janda, J. M. \& Abbott, S. L. (1998). Evolving concepts regarding the genus Aeromonas: an expanding panorama of species, disease presentations, and unanswered questions. Clin Infect Dis 27, 332-344.

Kämpfer, P., Christmann, C., Swings, J. \& Huys, G. (1999). In vitro susceptibilities of Aeromonas genomic species to 69 antimicrobial agents. Syst Appl Microbiol 22, 662-669.

Kumar, S., Tamura, K., Jakobsen, I. B. \& Nei, M. (2001). MEGA2: molecular evolutionary genetic analysis software. Bioinformatics 17, $1244-1245$.

Martínez-Murcia, A. J. (1999). Phylogenetic positions of Aeromonas encheleia, Aeromonas popoffii, Aeromonas DNA hybridization Group 11 and Aeromonas Group 501. Int J Syst Bacteriol 49, 1403-1408.

Martínez-Murcia, A. J., Antón, A. I. \& Rodríguez-Valera, F. (1999). Patterns of sequence variation in two regions of the $16 \mathrm{~S}$
rRNA multigene family of Escherichia coli. Int J Syst Bacteriol 49, 601-610.

Mesbah, M., Premachandran, U. \& Whitman, W. B. (1989). Precise measurement of the $\mathrm{G}+\mathrm{C}$ content of deoxyribonucleic acid by high-performance liquid chromatography. Int J Syst Bacteriol 39, 159-167.

Miñana-Galbis, D., Farfán, M., Lorén, J. G. \& Fusté, M. C. (2002). Biochemical identification and numerical taxonomy of Aeromonas spp. isolated from environmental and clinical samples in Spain. J Appl Microbiol 93, 420-430.

Pidiyar, V., Kaznowski, A., Narayan, N. B., Patole, M. \& Shouche, Y. S. (2002). Aeromonas culicicola sp. nov., from the midgut of Culex quinquefasciatus. Int J Syst Evol Microbiol 52, 1723-1728.

Pitcher, D. G., Saunders, N. A. \& Owen, R. J. (1989). Rapid extraction of bacterial genomic DNA with guanidium thiocyanate. Lett Appl Microbiol 8, 151-156.

Popoff, M. (1984). Genus III. Aeromonas. In Bergey's Manual of Systematic Bacteriology, pp. 545-548. Edited by N. R. Krieg \& J. G. Holt. Baltimore: Williams \& Wilkins.

Popoff, M. Y., Coynault, C., Kiredjian, M. \& Lemelin, M. (1981). Polynucleotide sequence relatedness among motile Aeromonas species. Curr Microbiol 5, 109-114.

Smibert, R. M. \& Krieg, N. R. (1994). Phenotypic characterization. In Methods for General and Molecular Bacteriology, pp. 607-655. Edited by P. Gerhardt, R. G. E. Murray, W. A. Wood \& N. R. Krieg. Washington, DC: American Society for Microbiology.

Stackebrandt, E. \& Goebel, B. M. (1994). Taxonomic note: a place for DNA-DNA reassociation and $16 \mathrm{~S}$ rRNA sequence analysis in the present species definition in bacteriology. Int J Syst Bacteriol 44, 846-849.

Thompson, J. D., Gibson, T. J., Plewniak, F., Jeanmougin, F. \& Higgins, D. G. (1997). The CLUSTAL_X windows interface: flexible strategies for multiple sequence alignment aided by quality analysis tools. Nucleic Acids Res 25, 4876-4882.

Valera, L. \& Esteve, C. (2002). Phenotypic study by numerical taxonomy of strains belonging to the genus Aeromonas. J Appl Microbiol 93, 77-95.

Wayne, L. G., Brenner, D. J., Colwell, R. R. \& 9 other authors (1987). International Committee on Systematic Bacteriology. Report of the ad hoc committee on reconciliation of approaches to bacterial systematics. Int J Syst Bacteriol 37, 463-464.

Wilson, K. (1987). Preparation of genomic DNA from bacteria. In Current Protocols in Molecular Biology, pp. 2.4.1.-2.4.5. Edited by F. M. Ausubel, R. Brent, R. E. Kingston, D. D. Moore, J. G. Seidman, J. A. Smith \& K. Struhl. New York: Greene Publishing and Wiley Interscience. 